\title{
EPIDEMIOLOGICAL PROFILE OF ACCIDENTS WITH EXPOSURE TO BIOLOGICAL MATERIALS THAT OCCURRED IN WORKERS IN THE STATE OF AMAPÁ, AMAZON, BRAZIL, FROM 2015 TO 2019
}

\section{ORIGINAL ARTICLE}

MACIEL, Danilo Pereira Garcia ${ }^{1}$, MEDEIROS, José Leandro Tomaz², SILVA, Mariana Freitas $\mathrm{da}^{3}$, SILVA, Matheus Freitas $\mathrm{da}^{4}$, FECURY, Amanda Alves ${ }^{5}$, DIAS, Claudio Alberto Gellis de Mattos $^{6}$, OLIVEIRA, Euzébio de ${ }^{7}$, DENDASCK, Carla Viana $^{8}$, DAHER, Donizete Vago ${ }^{9}$, ARAÚJO, Maria Helena Mendonça de ${ }^{10}$

MACIEL, Danilo Pereira Garcia. Et al. Epidemiological profile of accidents with exposure to biological materials that occurred in workers in the State of Amapá, Amazon, Brazil, from 2015 to 2019. Revista Científica Multidisciplinar Núcleo do Conhecimento. Year 06, Ed. 03, Vol. 04, pp. 127-141. March 2021. ISSN: 2448-0959, Access link: https://www.nucleodoconhecimento.com.br/health/biologicalmaterials, DOI: 10.32749/nucleodoconhecimento.com.br/health/biological-materials

\footnotetext{
${ }^{1}$ Undergraduate student in the Medicine Course at the Federal University of Amapá (UNIFAP).

${ }^{2}$ Undergraduate student in the Medicine Course at the Federal University of Amapá (UNIFAP).

${ }^{3}$ Undergraduate student in the Medicine Course at the Federal University of Amapá (UNIFAP).

${ }^{4}$ Undergraduate student in the Medical Course at the State University of Pará (UEPA)

${ }^{5}$ Biomedical, PhD in Topical Diseases, Professor and researcher of the Medical Course at Campus Macapá, Federal University of Amapá (UNIFAP).

${ }^{6}$ Biologist, PhD in Behavior Theory and Research, Professor and researcher of the Chemistry Degree Course at the Institute of Basic, Technical and Technological Education of Amapá (IFAP) and the Graduate Program in Professional and Technological Education (PROFEPT IFAP).

${ }^{7}$ Biologist, PhD in Topical Diseases, Professor and researcher at the Physical Education Course at, Federal University of Pará (UFPA) 8

${ }^{9}$ Nurse and Obstetrician, PhD in Public Health (FCM-UNICAMP), Professor and researcher at Universidade Federal Fluminense (UFF).

${ }^{10}$ Physician, Master in Teaching and Health Sciences. Professor and researcher at the Federal University of Amapá (UNIFAP), Macapá campus, AP.
}

RC: 78490

Disponível em: https://www.nucleodoconhecimento.com.br/health/biological$\underline{\text { materials }}$ 


\section{ABSTRACT}

Accidental exposures with sharp instruments are the most common occupational accidents involving professionals and students in a hospital environment. Accident with biological material (MB) results from direct contact between blood and genital or serous organic fluids, with unhealthy skin, mucous membranes or by direct percutaneous inoculation through sharp objects. The objective of this study was to characterize the epidemiological profile of accidents with exposure to biological materials that occurred in workers in the state of Amapá, Amazon, Brazil, in the period from 2015 to 2019, analyzing the number, type of occurrences, occupation and circumstance of the accident. A retrospective, descriptive, cross-sectional epidemiological study was carried out with a quantitative approach. Thus, the database of the Information System for Notifiable Diseases (SINAN) was searched for records referring to notifications of accidents with biological material, which occurred in the state of Amapá in the period from 2015 to 2019, registered by the Occupational Health Surveillance Center (NVST) / Reference Center for Occupational Health (CEREST / AP). Occupational exposures to biological materials pose a potential risk of disease transmission. Instructing workers to report accidents immediately is essential to supply the notification system. Regarding the circumstances, the two most commonly found causes were with values close to each other, the administration of medications (21.6\%) and inadequate disposal of the material (20\%). This incorrect disposal demonstrates the professionals' lack of zeal about their own health.

Keywords: Biological Accidents, exposure, epidemiology, Amazon, worker.

\section{INTRODUCTION}

Accidental exposures with sharp instruments are the most common occupational accidents involving professionals and students in a hospital environment. It is estimated that approximately 385,000 cases of sharps accidents involving health

RC: 78490

Disponível em: https://www.nucleodoconhecimento.com.br/health/biologicalmaterials 
professionals working in hospitals around the world occur annually, according to the Centers for Diseases Control and Prevention - CDC (RUAS et al., 2012; CUNHA te al ., 2019).

Accident with biological material (MB) results from direct contact between blood and genital or serous organic fluids, with unhealthy skin, mucous membranes or by direct percutaneous inoculation through sharp objects. Occupational exposure occurs during the exercise of work, either in services designed to provide health care to the population, or during waste collection or any other work function performed and makes up the National List of Compulsory Notification Diseases (BRASIL, 1991; DAROUICHE et al., 2014; ARAÚJO et al., 2019).

Among the more than twenty pathogens involved in accidental exposures, we highlight the Hepatitis B Virus (HBV), Hepatitis C Virus (HCV) and the Human Immunodeficiency Virus (HIV), due to the risk of transmission that is estimated between $6 \%$ and $30 \%$ for HBV; between $5 \%$ and $10 \%$ for HCV and $0.3 \%$ for $\mathrm{HIV}$, after injury with a piercing object (CDC, 2001). In addition to viral pathogens, the etiologic agent Clostridium tetani, causes accidental tetanus, through the inoculation of spores on mucous membranes and unhealthy skin, especially in deep superficial wounds involving materials with incorrect disposal (BRASIL, 2018; SILVA et al., 2020 ). The risk of acquiring an infection through these exposures depends on factors such as: extent of the lesion, volume of biological fluid present, systemic conditions of the victim, characteristics of the microorganisms present, serological status of the source person, as well as the conduct performed after the exhibition (BRASIL, 2017, VASCONCELOS et al., 2020).

Ordinance No. 1061/2020 establishes that Work Accidents with Exposure to Biological Material, is mandatory notification and must be inserted in the Notifiable Diseases Information System (SINAN) weekly. At the time of the accident attendance, it is necessary to fill in the individual notification form (FNI), however,

RC: 78490

Disponível em: https://www.nucleodoconhecimento.com.br/health/biological$\underline{\text { materials }}$ 
one should not wait for the FNI to be filled out to provide assistance to the worker (BRASIL, 2020).

The main way to avoid exposure is preventive education and the proper use of Personal Protective Equipment (PPE), thus observing biosafety standards. It is important to assess the serological status of both the exposed person and the source person. Post-Exposure Prophylaxis (PEP), should be initiated in the first hours of the accident, with HIV Antiretroviral Therapy (ART) being indicated as PEP for HIV, and recommendation for complementary vaccination or passive immunization for Viral Hepatitis and Tetanus (Brasil, 2017).

\section{OBJECTIVE}

To characterize the epidemiological profile of accidents with exposure to biological materials that occurred in workers in the state of Amapá, Amazon, Brazil, in the period from 2015 to 2019, analyzing the number, type of occurrences, occupation and circumstance of the accident.

\section{METHOD}

A retrospective, descriptive, cross-sectional epidemiological study was carried out with a quantitative approach. Thus, the database of the Information System for Notifiable Diseases (SINAN) was searched for records referring to notifications of accidents with biological material, which occurred in the state of Amapá in the period from 2015 to 2019, registered by the Occupational Health Surveillance Center (NVST) / Reference Center for Occupational Health (CEREST / AP).

In this sense, the variables analyzed included the total number of accidents, the number of cases separated per year, the occasion on which the accident occurred, biological sex and the occupation of the injured.

RC: 78490

Disponível em: https://www.nucleodoconhecimento.com.br/health/biologicalmaterials 
The numbers were obtained in the month of October 2020 through the export of records from SINAN by the Tabwin program, developed by DATASUS / Ministry of Health, to spreadsheets of the Microsoft Excel program. Then being compiled, tabulated and analyzed, they were calculated and expressed in absolute and relative frequencies and, finally, analyzed together with the literary research surveyed. Due to the public-administrative domain of secondary data, the opinion of the Research Ethics Committee was not required, according to Resolution 466-2012.

\section{RESULTS}

During the 2015-2019 five-year period, 860 cases of accidents with biological material were reported in SINAN. The year in which the most accidents occurred was $2016(199$ cases $=23.1 \%$ ), in contrast to the previous year, in which there was the lowest rate of records, $2015(128$ cases $=14.8 \%)($ Figure 1$)$.

RC: 78490

Disponível em: https://www.nucleodoconhecimento.com.br/health/biological- 
Figure 1 Shows the number of occupational accidents with exposure to biological material in the state of Amapá, Amazon, Brazil between 2015 and 2019.

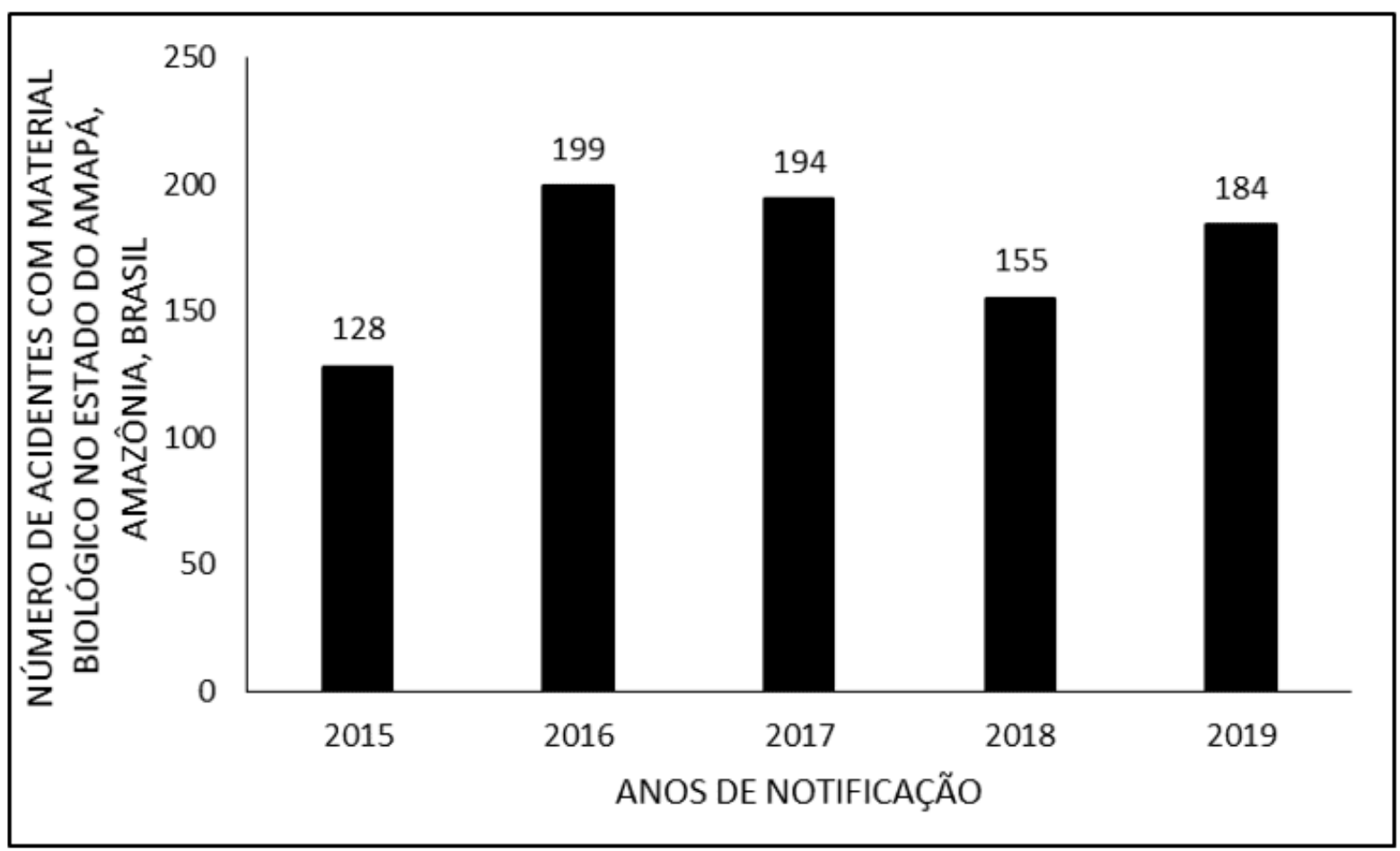

Source: SINAN, 2020.

RC: 78490

Disponível em: https://www.nucleodoconhecimento.com.br/health/biologicalmaterials 
The female sex with 595 cases $(69.1 \%)$ was predominant over the male, which occupied less than one third of the registered cases, 265 (30.8\%) (Figure2).

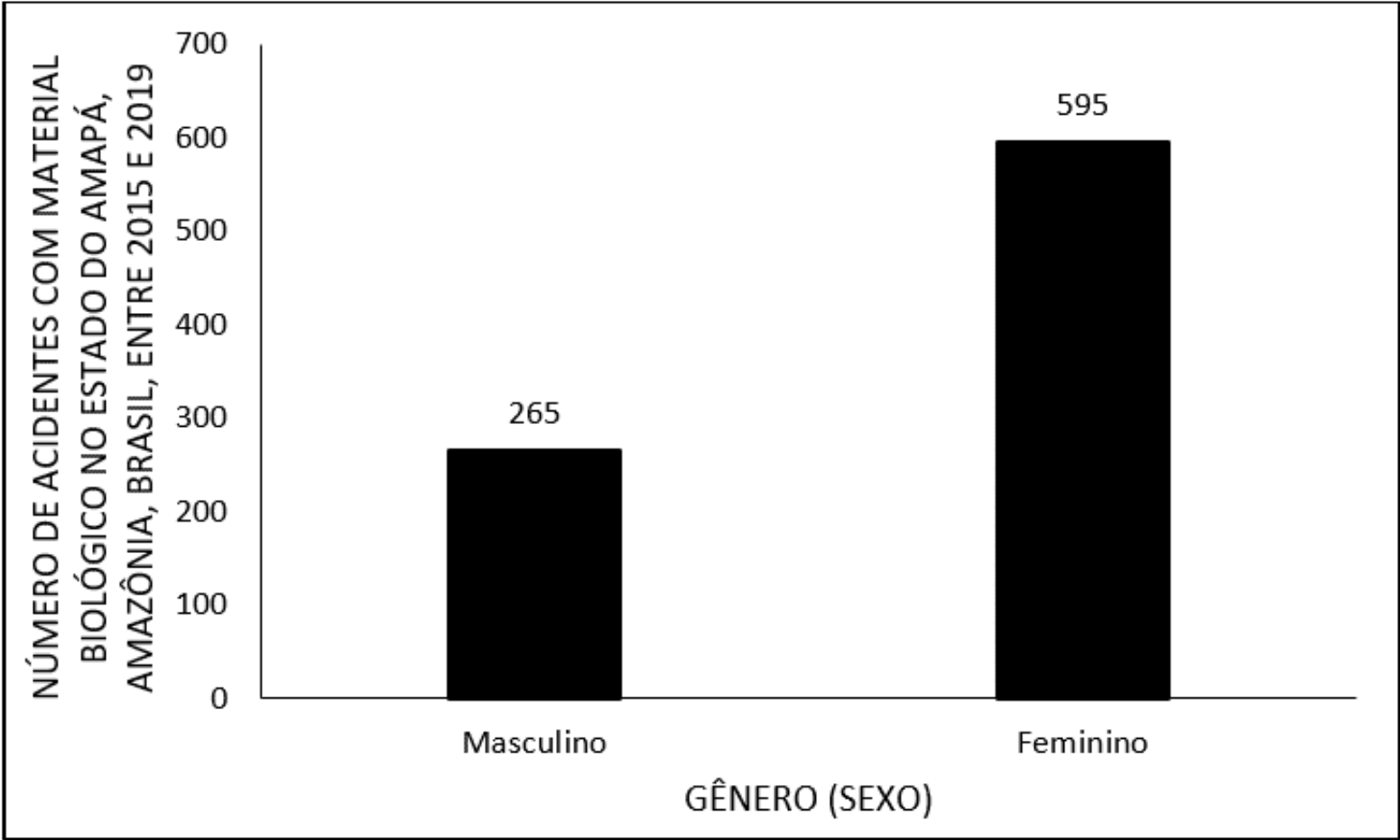

Source: SINAN, 2020.

Figure 2 Shows the number of occupational accidents with exposure to biological material in the state of Amapá, Amazon, Brazil between 2015 and 2019, by gender (sex).

As for professional occupation, the class most involved in accidents was that of nursing professionals (346 cases $=40.13 \%$ ), distributed as follows: 300 nursing technicians (34.9\%), 45 nurses $(5.23 \%)$. The second place is occupied by students, with 116 cases (13.4\%). Followed by the sanitation servers (janitors, garbage collectors and street cleaners), with a total of 66 cases (7.8\%). The medical class has 35 cases $(4.06 \%)$, when all specialties are added, with the highest incidence among clinical physicians (1.86\%) and general surgeons (1.04\%). Dental professionals represent 24 cases $(2.7 \%)$, however, dental hygiene technicians have a higher

RC: 78490

Disponível em: https://www.nucleodoconhecimento.com.br/health/biological$\underline{\text { materials }}$ 
number of accidents than 53 cases (6.16\%), when compared to dentists. Pharmacists, physiotherapists and biomedicals together, represent $1.62 \%$ of the total cases (Table 1).

Table 1 Shows the number of occupational accidents with exposure to biological material in the state of Amapá, Amazon, Brazil between 2015 and 2019, regarding occupation.

\begin{tabular}{c|c|c|c|c|c|c}
\cline { 2 - 7 } & $\mathbf{2 0 1 5}$ & $\mathbf{2 0 1 6}$ & $\mathbf{2 0 1 7}$ & $\mathbf{2 0 1 8}$ & $\mathbf{2 0 1 9}$ & TOTAL \\
\hline $\begin{array}{c}\text { Profissionais de } \\
\text { enfermagem }\end{array}$ & 73 & 70 & 76 & 65 & 62 & 346 \\
\hline $\begin{array}{c}\text { Estudantes } \\
\text { Gari, faximeiro, coletor de } \\
\text { lixo }\end{array}$ & 10 & 27 & 32 & 22 & 25 & 116 \\
\hline $\begin{array}{c}\text { Profissionais médicos } \\
\text { Cirurgião dentista }\end{array}$ & 3 & 13 & 8 & 4 & 7 & 35 \\
\hline $\begin{array}{c}\text { Outros profissionais de } \\
\text { saúde }\end{array}$ & 4 & 10 & 6 & 9 & 24 & 53 \\
\hline $\begin{array}{c}\text { Profissionais de outras } \\
\text { áreas }\end{array}$ & 14 & 71 & 52 & 29 & 32 & 198 \\
\hline TOTAL & $\mathbf{9 1}$ & $\mathbf{1 2 1}$ & $\mathbf{1 2 3}$ & $\mathbf{1 1 1}$ & $\mathbf{1 2 8}$ & $\mathbf{8 3 8}$ \\
\hline
\end{tabular}

Source: SINAN, 2020.

Considering the variable circumstance of the accident, the most common cause of injuries involving biological materials was the administration of medications (21.6\%), followed by inadequate disposal of material (20\%), and surgical and dental procedures (15\%). Two other notable causes were the handling of the sharps disposal box (3.9\%) and needle recapping (2.32\%) (Table 2).

RC: 78490

Disponível em: https://www.nucleodoconhecimento.com.br/health/biological- 
Table 2 Shows the number of occupational accidents with exposure to biological material in the state of Amapá, Amazon, Brazil between 2015 and 2019, according to the occasion.

\begin{tabular}{|c|c|c|c|c|c|c|}
\hline & 2015 & 2016 & 2017 & 2018 & 2019 & Total \\
\hline $\begin{array}{c}\text { Administração } \\
\text { endovenosa }\end{array}$ & 22 & 23 & 21 & 15 & 22 & 103 \\
\hline $\begin{array}{c}\text { Descarte inadequado } \\
\text { lixo }\end{array}$ & 20 & 17 & 21 & 18 & 18 & 94 \\
\hline $\begin{array}{c}\text { Descarte inadequado } \\
\text { chão }\end{array}$ & 13 & 16 & 26 & 9 & 14 & 78 \\
\hline $\begin{array}{l}\text { Procedimento } \\
\text { odontológico }\end{array}$ & 2 & 20 & 13 & 17 & 23 & 75 \\
\hline $\begin{array}{l}\text { Administração } \\
\text { intramuscular }\end{array}$ & 5 & 8 & 12 & 21 & 15 & 61 \\
\hline Procedimento cirúrgico & 4 & 21 & 12 & 4 & 13 & 54 \\
\hline Punção coleta & 9 & 7 & 5 & 6 & 9 & 36 \\
\hline $\begin{array}{c}\text { Manipulação de caixa } \\
\text { perfuro/cortante }\end{array}$ & 4 & 6 & 9 & 9 & 6 & 34 \\
\hline Lavagem de material & 6 & 4 & 8 & 3 & 10 & 31 \\
\hline $\begin{array}{c}\text { Procedimento } \\
\text { laboratorial }\end{array}$ & 2 & 2 & 4 & 5 & 10 & 23 \\
\hline Punção NE & 6 & 5 & 4 & 3 & 2 & 20 \\
\hline Lavanderia & 2 & 15 & 0 & 2 & 1 & 20 \\
\hline Reencape & 2 & 6 & 2 & 5 & 5 & 20 \\
\hline $\begin{array}{c}\text { Administração } \\
\text { subcutânea }\end{array}$ & 0 & 7 & 6 & 0 & 1 & 14 \\
\hline Dextro & 7 & 0 & 4 & 0 & 1 & 12 \\
\hline $\begin{array}{c}\text { Administração } \\
\text { intradérmica }\end{array}$ & 3 & 3 & 2 & 0 & 0 & 8 \\
\hline Ignorado/Branco & 4 & 10 & 11 & 11 & 2 & 38 \\
\hline Outros & 17 & 29 & 34 & 27 & 32 & 139 \\
\hline Total & 128 & 199 & 194 & 155 & 184 & 860 \\
\hline
\end{tabular}

Source: SINAN, 2020.

RC: 78490

Disponível em: https://www.nucleodoconhecimento.com.br/health/biological- 


\section{DISCUSSION}

Based on the data presented, it is possible to see that women are the main workforce involved in accidents with biological material (69.1\%). An analysis of a historical series launched in the format of an epidemiological bulletin carried out in Rio de Janeiro between the years 2009-2020, revealed an approximate proportion of one man for every three women who suffer an accident (Brasil, 2020; CARNEIRO et al., 2020). A similar result was found in the study by Khalil et al., (2015) carried out in a specialized care service in southeastern Brazil, where women suffered three times more accidents compared to men.

Among the analyzed occupations, the category of health professionals $(60.11 \%)$ was noted as being the main victims, this is due to the fact that these professionals are in direct contact with patients, performing procedures and handling potentially contaminated materials (MOREIRA et al., 2020). These findings were equivalent to studies carried out in other countries such as Egypt and Italy (TALAAT et al., 2003; MAIDA et at., 2020).

According to the results of the research on screen, nursing professionals were the category most involved in accidents, followed by students, corroborating the finding of Santos (2015) who in his research demonstrated that nursing technicians followed by medical students were the most affected by sharps accidents. In this sense, there is also the study by Kon et al (2011) in a Hospital in Curitiba (PR) in which most accidents affected nursing assistants (30.1\%), nursing technicians $(15 \%, 2)$ and students $(10.8 \%)$ notified and registered with SINAN.

Figueiredo (2018), analyzing the professionals involved in accidents with biological materials, observed that, among the cases analyzed, $47 \%$ worked in the nursing area; $19 \%$ were students, $6 \%$ were doctors; $6 \%$ dentist surgeons, $4 \%$ were workers in the collection, waste, cleaning and conservation services of public areas. Corroborating these data, nursing technicians appear first, with more than a third of

RC: 78490

Disponível em: https://www.nucleodoconhecimento.com.br/health/biological$\underline{\text { materials }}$ 
published accident cases. These professionals constitute the largest number of workers in the services, directly providing assistance to patients (NEIVA et al., 2019). Oliveira et al. (2015), published an epidemiological study of accidents with MB among nursing professionals in a city in Ceará, out of 277 accident reports, 217 were nursing assistants $(78.3 \%)$, confirming that these professionals are the most exposed to accidents.

Students constitute the second predominant category in accidents with biological material, corresponding to $13.4 \%$ of the total analyzed. This may be due to the fact that they are undergoing training and education, therefore showing professional inexperience during the technical performance of procedures and material handling. Reis et al. (2013) conducted an epidemiological study of accidents with biological material in a surgical emergency room involving medical students, and found that among the 100 participating students, a percentage of $32 \%$ suffered this type of accident in 2012. The main factors identified in this study there was a lack of training and no use of personal protective equipment.

It is also important to highlight the professionals who work in cleaning, as they represent the third group with the highest risk of contamination with biological material, as they have direct contact with organic and hospital waste (MATOS et al., 2019). They are represented by garbage collectors, janitors and street cleaners. Canini; Gir and Machado (2005) developed a study in which support service workers who suffered accidents with a potential risk of contamination were followed up in a tertiary university hospital in São Paulo for a period of approximately four years. It was found that the majority (94.9\%) of the accidents was not possible to discover the source person, requiring PEP with the use of ART and it was due to the incorrect disposal of needles.

With the result of these data, there is a difference in the number of accidents comparing different categories of health professionals. Doctors $(4.06 \%)$ have a higher incidence than dentists (2.7\%) in the state of Amapá. Correspondingly, it was

RC: 78490

Disponível em: https://www.nucleodoconhecimento.com.br/health/biologicalmaterials 
found in the study by Reis, Gómez, Diniz (2019), that physicians had a higher incidence than dentists, explained by the better adherence to standard precautionary measures. The same pattern was repeated among medical students versus dentistry - better adherence to standard precautions.

According to Brozoski (2010) the accident with biological material occurs during practices in surgery disciplines in the dentistry course with anesthesia needle material that are hypodermic and gingival. The data show that the dental surgeon is in fifth place with 24 cases during the period, and intradermal drug administration has only 8 reported cases, which creates scope for considering a hypothesis of underreporting, which can happen in more than $95 \%$ of cases according to Santos (2015).

When confronted with the difference in cases of accidents with MB between doctors of clinical and surgical specialties, in Amapá, there is a predominance of the first over the second. Unlike what was observed in a university hospital in Colombia, where doctors residing in surgical areas had 3.3 times more accidents than doctors.

residents of clinical areas. (TAPIAS, TAPIAS, TORRES, 2007). This difference is possibly due to the lack of uniformity of prevention between places and work, even though there are unique rules (MATOS et al., 2019).

Regarding the circumstances, the two most commonly found causes were with values close to each other, the administration of medications (21.6\%) and inadequate disposal of the material (20\%). This incorrect disposal demonstrates the professionals' lack of zeal about their own health. Cordeiro et al. (2016), found very similar results also involving medication administration (9.7\%) and inappropriate material disposal (9.5\%) in their research conducted in the state of Bahia in 2012, with data from 1613 SINAN cases. In contrast, Janjua, Khan, Mahmood (2010), observed in their study that needle recapping was the most common cause of an accident, as it increased the risk of percutaneous exposure by two times.

RC: 78490

Disponível em: https://www.nucleodoconhecimento.com.br/health/biologicalmaterials 


\section{CONCLUSIONS}

Occupational exposures to biological materials represent a potential risk of disease transmission. There are still some challenges to be overcome in relation to notification and preventive actions in industrial accidents involving workers in Amapá

Instructing workers to report accidents immediately is essential to supply the notification system. The data correctly filled in the notification form is important to help monitor the occurrence of accidents, ensure an early follow-up to mitigate the chance of contracting infections, to identify higher risk activities, in order to reinforce surveillance and improve biosafety practices and reduce risks. occupational risks.

The main ways to prevent accidents at work are to observe and follow safety measures such as the proper use of PPE, caution when administering medications, correct disposal of materials, complete and updated vaccination schedule for hepatitis B and tetanus and post-prophylaxis -exhibition with adequate monitoring. The prevention of these infections is an important pillar in worker safety.

\section{REFERENCES}

ARAÚJO, A. F. B. et al. Internações por acidentes de trânsito no Estado do Amapá entre os anos 2014-2018 Revista Científica Multidisciplinar Núcleo do Conhecimento, v. 1 , p. 1-10, 2019. Disponível em:< https://www.nucleodoconhecimento.com.br/saude/internacoes-por-acidentes >.

BRASIL. Portaria no 1061, de 18 de maio de 2020. Revoga A Portaria № 264, de 17 de Fevereiro de 2020, e Altera A Portaria de Consolidação № 4/gm/ms, de 28 de Setembro de 2017, Para Incluir A Doença de Chagas Crônica, na Lista Nacional de Notificação Compulsória de Doenças, Agravos e Eventos de Saúde Pública nos Serviços de Saúde Públicos e Privados em Todo 0 Território

RC: 78490

Disponível em: https://www.nucleodoconhecimento.com.br/health/biologicalmaterials 
Nacional. 102. ed. Brasília, DF: Ministério da Saúde, 29 maio de 2020. Seção 1, p. 229.

BRASIL. Constituição (1990). Lei no 8213/91, de 24 de julho de 1991. Brasília, DF. 1991. Disponível em: http://www.planalto.gov.br/ccivil_03/leis//8213cons.htm. Acesso em: 18 fev. 2020.

BRASIL. Ministério da Saúde. Protocolo Clínico e Diretrizes Terapêuticas para Hepatite B e Coinfecções. Brasília: Secretaria de Vigilância em Saúde, Departamento de DST, Aids e Hepatites Virais, Ministério da Saúde, 2017.

BRASIL. Ministério da Saúde. Guia de Vigilância em Saúde: volume único. 2a edição. Brasília: Secretaria de Vigilância em Saúde, Coordenação-Geral de Desenvolvimento da Epidemiologia em Serviços. Ministério da Saúde, 2017.

BRASIL. Ministério da Saúde. Protocolo clínico e diretrizes terapêuticas para profilaxia pós-exposição (PEP) de risco à infecção pelo HIV, IST e hepatites virais. Brasília: Ministério da Saúde, 2017, p 164-172, volume único. Disponível em: Volume-Unico-2017.pdf (saude.gov.br) . Acesso em :10/02/2020.

BRASIL. Ministério da Saúde. Boletim Epidemiológico: Situação epidemiológica do tétano acidental no Brasil, 2007-2016. Volume 49/ Jun. 2018. Brasília: Secretaria de Vigilância em Saúde, 2018.

BROZOSKI, M.A.; Traina A.A.; NACLÉRIO-HOMEM, M.G.; DEBONI, M.C.Z. Ocorrência de acidentes perfurocortantes em um curso de odontologia. Rev Gaúcha Odontol, Porto Alegre: vol.58 n.1, p 77-80, 2010.

CANINI S.R.M.S.; GIR, E.; MACHADO, A. A. Accidents with potentially hazardousbiological material among workers in hospital supporting services. Revista Latino-Americana de Enfermagem, Ribeirão Preto, v. 13, n. 4, p. 496-500, jul/ago, 2005.

RC: 78490

Disponível em: https://www.nucleodoconhecimento.com.br/health/biologicalmaterials 
CARNEIRO, L. Q. C. et al. Perfil epidemiológico dos pacientes atendidos devido a acidentes ofídicos no norte do Brasil, Região Amazônica, no período de 2009 a 2019. Revista Científica Multidisciplinar Núcleo do Conhecimento, v. 3, p. 1-19, 2020. Disponível em: < https://www.nucleodoconhecimento.com.br/saude/acidentesofidicos $>$.

CDC. Guidelines for the management of occupational exposures to HBV, HCV, and HIV and recommendations for postexposure prophylaxis. Atlanta: MMWR Recomm Rep, v50(RR11),P 1-52, 2001.

CORDEIRO, T. M. S. C.; NETO, J. N. C.; CARDOSO, M. C. B. C.; MATTOS, A. I. S.; SANTOS, K. O. B.; ARAÚJO, T. M. Acidentes de trabalho com exposição à material biológico: Descrição dos casos na Bahia. Rev. Epidemiol. Control. Infec, Santa Cruz do Sul, v. 6, n. 2, p. 50-56, 2016.

CUNHA, A. A. et al. Tendência na incidência de acidentes de trajeto em trabalhadores no Brasil entre 2009 e 2016. Bras Med Trab., v. 17, n. 4, p. 490-498, 2019. Disponível em: < http://rbmt.org.br/about-the-authors/489/pt-BR >.

DAROUICHE, M.H., et al. Occupational blood exposure among health care personnel and hospital trainees. Int J Occup Environ Med. [S.I], v.5, n 1, p 57-61, 2014

FIGUEIREDO, W. M.; et al. Acidentes ocupacionais por material de risco biológico: estudo etnográfico. Braz. J. of Develop, Curitiba, v. 4, n. 7, Edição Especial, p. 4500-4518, nov. 2018.

JANJUA, N.Z.; KHAN, M.I.; MAHMOOD, B. Sharp injuries and their determinants among health care workers at first-level care facilities in Sindh Province, Pakistan. Trop Med Int Health, [S.I] v15, p 1244-1251, 2010.

$\mathrm{RC}: 78490$

Disponível em: https://www.nucleodoconhecimento.com.br/health/biologicalmaterials 
KHALIL, S.S.; KHALIL, O.A.K.; LOPES-JÚNIOR, L.C.; CABRAL, D.B.; BOMFIM, E.O.; LANDUCCI, L.F.; SANTOS, M.L.S.G. Occupational exposure to bloodborne pathogens in a specialized care service in Brazil. American Journal of Infection Control, [S.I], v43, n8, p. e39-e41, 2015.

KON, N.M.; SOLTOSKI, F.; REQUE JÚNIOR. M.; LOZOVEY, J.C.A. Acidentes de trabalho com material biológico em uma Unidade Sentinela: casuística de 2.683 casos. Rev Bras Med Trab. [S.I], v 9, n 1, p 33-38, 2011.

MAIDA, C.M.; APREA, L.; CALAMUSA, G.; CAMPISI, F.; FAVARO, D.; FIORINO, G.R.; FODALE, A.M.; MANIGLIA, M.L.; MARCHESE, V.; VELARDO, M.M.; Torregrossa M.V. Blood and body fluids exposure of healthcare workers in a university hospital of Palermo, Italy: a fourteen years long surveillance. Annali di Igiene, [S.I], Volume 32, n6, 2020.

MATOS, D. V. D. et al. Caracterização epidemiológica dos indivíduos que sofreram acidentes de trabalho nas macrorregiões brasileiras, nos anos de 2016 a 2018. Revista Científica Multidisciplinar Núcleo do Conhecimento, v. 1, 2019. Disponível em: < https://www.nucleodoconhecimento.com.br/saude/acidentes-detrabalho $>$.

MOREIRA, E. C. D. M. et al. Impactos diretos e indiretos na neurocognição humana, decorrentes da intoxicação por metilmercúrio e seus agravos para a saúde coletiva. Research, Society and Development, v. 912, p. e4409128005, 2020. Disponível em: < https://rsdjournal.org/index.php/rsd/article/view/8005 >.

NEIVA, C. A. C. et al. Caracterização epidemiológica das intoxicações exógenas por substâncias nocivas e acidentes por animais peçonhentos em crianças no Estado do Amapá. Revista Científica Multidisciplinar Núcleo do Conhecimento, v. 1, p. 4166 , 2019.

Disponível em: https://www.nucleodoconhecimento.com.br/saude/caracterizacao-epidemiologica >.

RC: 78490

Disponível em: https://www.nucleodoconhecimento.com.br/health/biologicalmaterials 
OLIVEIRA, Elizarbio Carneiro de. Analise epidemiológica de acidentes de trabalho com exposição a material biológico entre profissionais de enfermagem, SANARE, Sobral, v14, n1, p27-32, 2015.

REIS, L.A.; GÓMEZ LA-ROTTA, E.I.; DINIZ, P.B.; AOKI, F.H.; JORGE, J. Occupational Exposure to Potentially Infectious Biological Material Among Physicians, Dentists, and Nurses at a University. Safety and Health at Work, v 10, n4, p 445-451. 2019.

REIS, Phillipe Geraldo Teixeira de Abreu et al. Perfil epidemiológico de acidentes com material biológico entre estudantes de medicina em um pronto-socorro cirúrgico. Revista do Colégio Brasileiro de Cirurgiões. Rio de Janeiro: v. 40, n. 4, p.287-292, ago. 2013.

RUAS, Edna et al. Acidentes ocupacionais com materiais perfurocortantes em hospitais de Montes Claros-MG. Revista Mineira de Enfermagem, [S.I], v16, n3 p437-443, jul./set., 2012.

SANTOS Junior EP, et al. Acidentes de trabalho com material perfurocortante envolvendo profissionais e estudantes da área da saúde em hospital de referência. Rev. Bras. Med. Trab. [S.I], v 13, n 2, p 69-75, 2015

SILVA, L. F. et al. Casos confirmados de botulismo no brasil no decênio 2010 a 2019: Uma análise das notificações. In: GALVÃO, P. V. M. (Ed.). Saúde Pública no século XXI: Uma abordagem sobre a epidemiologia. Triunfo PE: Omnis Scientia, v. 1 , 2020. cap. 8 , p.72-84.

TALAAT, M. Occupational exposure to needlestick injuries and hepatitis B vaccination coverage among health care workers in Egypt. American Journal of Infection Control, v 31, n 8, p 469-474, 2003.

RC: 78490

Disponível em: https://www.nucleodoconhecimento.com.br/health/biologicalmaterials 
TAPIAS, L.F.; TAPIAS L.; TORRES, S.A. Accidentes biológicos en estudiantes de Medicina. Revista de la Universidad Industrial de Santander, [S.I], v 39, n 3, p 183-189, 2007.

VASCONCELOS, A. C. et al. Acidentes com materiais biológicos envolvendo estudantes da área da saúde no período de 2008-2018. In: SILVA, B. R. D. (Ed.). Difusão do conhecimento através das diferentes áreas da medicina 5. Ponta Grossa PR: Atena Editora, v.5, 2020. cap. 5, p.38-59.

Sent: March, 2021.

Approved: March, 2021.

RC: 78490

Disponível em: https://www.nucleodoconhecimento.com.br/health/biological$\underline{\text { materials }}$ 